\title{
«ПРИКРІ НЕСПОДІВАНКИ» МОВНОЇ СПОРІДНЕНОСТІ I ХУДОЖНІЙ ПЕРЕКЛАД
}

\begin{abstract}
Стецик М. С. «Прикрі несподіванки» мовної спорідненості і художній переклад.

У статті на прикладах різночасових російських (спорадично - польських) перекладів новел Василя Стефаника закцентовано на «підводних рифах» і небезпеках перекладу зі споріднених мов. Зазначено, що незначні відмінності на лексичному й граматичному рівнях набували принципового значення при спробі механічно відтворити Стефаникові слова і словесні образи цільовими мовами.

Ключові слова: переклад, Василь Стефаник, цільова мова, мовна спорідненість, реалія, ідіоматика, діалект, рецепція.

Стецык М. С. «Досадные неожиданности» языкового родства и художественный перевод.

В статье на примерах разновременных русскоязычных (спорадически польскоязычных) переводов новелл Василя Стефаника акцентируется на «подводных рифах» и опасностях перевода с родственных языков. Отмечается, что незначительные отличия на лексическом и грамматическом уровнях приобретали принципиальное значение при попытке механически воспроизвести слова и образы Василя Стефаника.

Ключевые слова: перевод, Василь Стефаник, целевой язык, языковое родство, реалия, идиоматика, диалект, рецепция.
\end{abstract}

Stetsyk M. S. "Unpleasant accidents" of language affinity and literary translation.

Investigating Russian (sporadically - Polish) translations of short stories by Vasyl Stefanyk this article represents "underwater reefs" while translating the related languages. It indicates that minor differences in grammatical and lexical levels become of great importance in mechanical interpreting Stefanyk's words and verbal images by means of 
chosen target languages.

Key words: translation, Vasil Stefanik, the target language, language affinity, reality, idiomatics, dialect, reception.

Творчість багатьох українських письменників часто ставала випробуванням на професійну зрілість навіть визнаних майстрів «високого мистецтва». Василь Стефаник належить до тих митців, чия новелістика завжди перебувала на вістрі літературознавчих і мовознавчих зацікавлень. Уже перші його образки інспірували жваве обговорення, гострі дискусії, емоційні відгуки й рецензії. 3 кожною новою збіркою - новий спалах рефлексій і чергова спроба осягнути феномен «мужицького Бетховена», «абсолютного пана форма». Коли вийшли друком перші переклади польською мовою, письменник висловив думку, що його твори, очевидно, нікому не вдасться добре перекласти: «Жицє» помістило переклади польські «Катрусі» і «Новини» <..> На перекладах у «Жицю» переконався, що моїх новел, відай, не можна перекладати на жодну мову. Виходить зле» [Цит. за: 6, с. 62]. Тобто практичного володіння мовами виявилося занадто мало, щоб розкрити в перекладах таїну говіркових слів, їхню глибоку імпліцитну філософію. У контексті слов'янської і світової рецепції новелістики В. Стефаника чільне місце належить російським і польським перекладам.

Мета полягає в тому, щоб крізь призму російських (задля рельєфності - польських) перекладів новел Василя Стефаника закцентувати на «підводних рифах» і небезпеках перекладу зі споріднених мов, почасти розвінчати міф про позірну легкість згаданої трансляції.

Проблему сприйняття творчості $\mathrm{B}$. Стефаника у слов'янському світі докладно висвітлено в монографії Ф. Погребенника «Василь Стефаник у слов'янських літературах» (1976). У своїй статті ми також спираємося на праці, що допомагають передовсім системно осмислити стрижневі проблеми перекладацької діяльності й випрацювати певну методологію наукового опису й оцінювання і конкретних перекладів, i окремих лінгвостилістичних та художньо-естетичних явищ (К. Чуковський, М. Рильський, О. Кундзіч, С. Ковганюк, В. Коптілов, О. Федоров, І. Лєвий, П. Тороп, М. Гольберг, Р. Зорівчак, М. Новикова). У науковій студії розглядаємо цільові тексти М. Ляшка, Г. Шипова, А. Дєєва, В. Россельса, М. Мочульського, тобто тих, хто системно перекладав твори В. Стефаника.

Аксіоматично, що феномен національного неможливо відтворювати лише адекватними з погляду змістової співвіднесеності одиницями цільової мови. Діалектизми, реалії, етномовні елементи, ідіоматика у В.Стефаника не лише становлять підгрунтя його () М. С. Стецик, 2015. $-356-$ 
оригінальної поетики, але й виражають надтекстові й затекстові особливості новел, формують лінгвоментальний ореол персонажів.

Переклад реалій - це справа i перекладацької техніки, i перекладацького мистецтва. Залежно від домінування того чи того виду інформації, що іiі несе реалія в кожному конкретному випадку (денотативної, конотативної, зокрема національно-культурної, локальної), від композиційної заданості реалії у контексті, перекладачі повинні відповідно відтворювати ії семантико-стилістичні функції [4, с. 142-143].

Ось перед читачем закам'яніла від горя постать батька, син якого «стратився» у війську («Стратився»): У кутку на лаві сидів мужик та плакав. Аби єго ніхто не бачив, щуо плаче, то ховав голову у писану maйстру [10, с. 17]. Батько їде до далекого міста, де загинув, не витримавши військової муштри, його єдиний син. Писана тайстра згадується в новелі кілька разів i, завдяки майстерності автора, підноситься до рівня мистецького узагальнення в епізодах, що зображають ключові моменти трагедії: на неї падають важкі батькові сльози, що безупинно пливуть з його очей; з тайстрою на колінах сидить батько у чужому місті під холодними мурами; писану тайстру, за звичаєм, батько поклав мертвому синові під голову. Відомий львівський дослідник I. Денисюк побачив у писаній тайстрі, що наповнюється слізьми, символічну скульптуру людського горя. Єдина в новелі етнографічна деталь - промовистий символ, котрий, на думку Р. Зорівчак, має увійти у «вічне теперішнє» світової літератури [4, с. 143].

Ф. Погребенник, аналізуючи ранні російські переклади Стефаника, зауважив, зокрема, невдале відтворення цісї реалії Є. Фуксом: Чтобы никто не видел его слез, он уткнул голову в пестро вышитый кожаный мешок [6, с. 67]. Вдавшись до гіперонімічного перейменування, перекладач не лише досить примітивно і не зовсім коректно змалював російському читачеві саму реалію (тайстра - це торбинка, яку носять через плече, а не мішок), але й цим докладним описовим зворотом надав їй зайвої етнографічної ваги. Він також не залишив жодного натяку на символічне узагальнення реалії. Спірним є переклад М. Мочульського - «kolorowa chustka». «Кольорова $\boldsymbol{x y c m \kappa a » ~ - ~ р е а л і я ~ п о л ь с ь к о г о ~ п о б у т у , ~ а ~ ц е ~ в ж е ~ п о л о н і з а ц і я ~ н а ~}$ етнокультурному рівні. Лише В. Россельс уважно й обережно підійшов до «писаної тайстри». Знайомлячи російського читача 3 невідомим йому атрибутом покутського побуту, він спочатку вдається до комбінованоописового перекладу У двох інших епізодах новели реалія вже активно функціонує в сюжеті як вагома художня деталь: Чтоб никто не видел его слез, он прятал голову в богато расшитую суму-тайстру [14, с. 7]. 
Умовою адекватного відтворення реалій $\epsilon$ їх глибоке розуміння. Часто перекладач зіштовхується із ситуацією, коли розуміння нібито $\epsilon$, але слова ще немає. Тлумачний словник (словники) не завжди може допомогти, адже він орієнтується не на якусь іншу мову, а лише на свою, лексичний склад якої повинен якнайповніше відобразити. На жаль, лексикографічні джерела мало коли включають слова, що 3 лінгвокраєзнавчого погляду виступають як реалії, недостатньо або й взагалі не представляють їхньої конотативної семантики. У новелі «Синя книжечка» перекладачі буквально спіткнулися на діалектній реалії «прощі»: - Адi, там коло воріт піп прощі казав. Увес мир плакав. Порьидна, каже, була жона, працовита... [10, с. 15].

Прощі - «надгробне слово», «похоронна проповідь» [9, с. 157]. Зазвичай акцент робиться на добрих вчинках. Від імені покійного священик просить вибачення у присутніх і прощається 3 ними. Прощальне слово - обов'язковий момент похоронного обряду. Його ще називають «подяка», «дякування». Г. Шипов і В. Россельс відтворили цю промовисту реалію генералізованими семантичними варіантами: А вон там у ворот поп панихиду правил. Весь народ плакал. Хорошая, говорит, была жена, работящая [11, с. 14]; Вон там, у ворот, поп отходную читал. Все село плакало. Хорошая, говорят, была женщчина, работящзая [14, с. 6].

Перестворення на рівні відповідності архисем вносить певну суперечність у текст всього уривку. В. Россельс слова, які виголошував саме священик про дружину Антона, переадресовує невизначеній третій особі («говорят»). Тобто є загальне розуміння ситуації, але приблизне відтворення реалії не дає змоги російському читачеві побачити важливий момент покутського похоронного обряду. М. Ляшко відтворив етнолексему дескриптивом «прощальне слово»: Вон там у ворот non прощальное слово говорил над покойнищей. Все люди плакали. Порядочная, говорит, женщина была, работящая [12, с. 26].

Лише з його перекладу російський читач може збагнути суть подій. Тут ідеться насамперед, як це влучно визначила М. Новикова, не про зіставлення слова зі словом, навіть не лише твору оригінального й перекладного, а й традиції з традицією [5, с. 109].

Цікаво порівняти російські переклади з польським : - Patrzcie, tam kolo wrot pop mial predmowe ...[16, 106]. Відповідник «predmowe» (букв. - «слово», «промова») актуалізує суттєві семантичні компоненти, не порушує мовностилістичної й етнокультурної рівноваги між текстами. Білоруський дослідник В. Рагойша зазначає, що при перекладі зі споріднених мов допомога дуже часто йде поруч з бар'єрами. Іноді ○ М. С. Стецик, 2015. 
надзвичайно зрадливою $є$ ця спорідненість і криє у собі багато прикрих несподіванок [7, с. 62].

У В. Стефаника художньо вагомими, емоційно та стилістично вмотивованими $\epsilon$ різноманітні граматичні форманти, певні синтаксичні форми, особливості звукового оформлення. Герой новели «Камінний хрест» Іван Дідух, підводячи своєрідний підсумок життя на рідній землі в момент остаточної розлуки з нею, з болем і розпачем говорить: Я на нім [горбі] вік свій спендив і окалічів-см [10, с. 68] (пор.: - Я на нем жнизь свою положил, на нем и покалечился [11, с. 83]; Я на нем век свой избыл и покалечился [12, с. 36]).

Лексема «спендити» подає одночасно кілька сигналів: це діалектизм (за походженням - фонетично не пристосований полонізм), входить до складу усталеного звороту, стилістично яскраво забарвлена. Завдання перекладачів ускладнюється ще й тим, що в слові яскраво виявляється енантіосемія, тобто одночасна актуалізація двох полярних значень, адже в діалекті «спендити» - це «прожити», «промучити», «провести» і «згайнувати», «змарнувати». Потенційні семи й відповідні асоціації у перекладах втрачено. Фразеологізовані дескриптиви «жизнь свою положил» та «век свой избыл» передають лише загальний сенс досліджуваного слова. 3 підтексту в затекст автоматично переводиться неоднорідність, суперечливість ситуації та психологічного стану персонажів, передусім Івана Дідуха. Постійна душевна роздвоєність емігранта (любов до рідної землі чи обов'язок супроти сім’і) формує у свідомості читача відповідний «експресивний ореол» цього персонажа

М. Рильський, перераховуючи численні «пастки», які чигають на перекладачів, зокрема, звернув увагу й на небезпеку нарядження «мови перекладу в дуже національні, специфічно національні шати» [8, с. 58]. Перекладачі, на жаль, не змогли подолати спокуси експресивнонаціонального (російського) перелицювання як окремих слів, так i художніх образів загалом. У нашому випадку це стосується тих художніх означень, в основі яких лежать діалектні лексеми. Іван Дідух («Камінний хрест») звертається до куми Тимофіхи, згадуючи молоді літа: - Oто-сте були хлопєнна дівка, годна-сте були [10, с. 65]. «Хлопєнна дівка» - дуже міцна. Перекладачі запропонували три різні варіанти: «бравая» (Дєєв), «ядреная» (Шипов), «крепкая》 (Россельс). 3 погляду адекватності експресивних форм найбільш вдалим видається варіант Г. Шипова. Одначе лексема «ядреная», по-перше, полісемантична, а це послаблює можливості іiі індивідуалізації (означення «хлопєнна» може бути адресоване лише людині, а валентність прикметника «ядреный» набагато 
ширша - плід, горіх, мороз, повітря, слова, погода ); по-друге, вона яскраво національно маркова (завдяки російським народнопоетичним образам), тобто актуалізовані передовсім індивідуальні асоціації перекладача. Варіант «бравая» (А. Дєєв) покриває лише частину конотацій оригіналу. Як не дивно, але саме нейтральний семантичний аналог В. Россельса «крепкая» найбільше відповідає оригіналові. Об'єктивно неперекладною виявилася й оксиморонна форма епітета («хлопєнна дівка», тобто «дівка, як хлоп»).

В основі епітета «дрантивий голос» («Святий вечір») лежить яскравий експресоїд-діалектизм. Г. Шипов відтворив його семантичним аналогом «надорванный голос», а В. Россельс - «дребезжащий голос». Одначе назвати їх адекватними до оригінального все-таки не можна. «Надорванный» не відповідає вимогам експресивно-стилістичного узгодження (в оригіналі - прикметник-діалектизм, з відтінком просторіччя, у перекладі - нейтральний, що в контексті набуває конотації піднесеності). Інша важлива сема - «старечий» - у цільових текстах не представлена.

У кількох новелах бачимо експресивну, колоритну фразему «шляк трафив». Виходячи 3 критеріїв нерозкладності та злютованості компонентів, це фразеологічне зрощення, чи ідіома. А. Федоров застерігав, що не варто наголошувати на перекладності цих одиниць у буквальному сенсі. Буквальний смисл, тобто пряме, номінативне значення компонентів ідіоми вже не сприймається навіть носіями мови оригіналу внаслідок втрати мотивування чи затемнення внутрішньої форми реалії, що входить до складу цього фразеологізму [15, с. 161-162]. Ідіома-прокляття «шляк трафив» (-ть) найчастіше вживається у граматичних варіантах: «бодай (най,

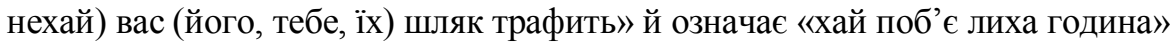
(шляк - букв.: «удар, апоплексія»). Якщо запитати пересічного галичанина, у мовленні якого частенько «проскакує» згаданий вислів, що ж це означає, то він навряд чи зуміє відповісти, зате яскраво проілюструє добрий десяток мовленнєвих ситуацій, де можна його використати. Іван (новела «В корчмі») на скарги Проця, що того б’є жінка, емоційно резонує: - Ого, вже най того вола шияк трафит, щзо го корова б' $\epsilon$ [10, с. 20].

Яскравий стилістичний малюнок фрази й контекст визначають рівень емоційного заряду ідіоми. Г. Шипов буквально сприйняв і відповідно скалькував лексичне значення окремо взятих компонентів: Ого, да расииби паралич того быка, которого корова бодает [11, с. 32].

Фразеологічна покомпонентна калька не лише завдала емоційноекспресивного «удару» фразі, позбавила ії стилістичної однорідності, але й спотворила семантичне поле. Ідіомам однієї мови можуть і найчастіше ( М. С. Стецик, 2015. 
повинні відповідати такі ідіоми, які $є$ їх адекватними смисловими i стилістичними відповідниками, не збігаючись 3 ними лексичним змістом окремих компонентів. Варіант Россельса максимально послаблений емотивно: Пропадай тот вол, которого корова бъет [14, с. 9].

Семантико-експресивну рівновагу ідіоми в цільовому тексті зумів зберегти лише М. Ляшко: Ого, пускай вола серп по бокам гладит, если его корова бьет [13, с. 19].

Залежно від контексту, тобто від певної мовленнєво-психологічної ситуації, адекватність ідіоми визначається не іï безпосередньою семантикою (першим змістовим шаром), а насамперед образними експресивними конотаціями. Г. Шипов так і не зміг подолати «гіпнозу слова», окремого компонента фразеологічної одиниці, і тому його версія справляє не зовсім те, а радше - зовсім не те враження. Оскільки ідіоми являють яскраво національну ознаку мови, вони й у перекладі мають виглядати як народні, щоб їх органічно, як щось своє і близьке, міг сприйняти читач. Тут цілком справджується знамените й, здавалось би, парадоксальне застереження Ш. Баллі: «Власне факт злютованості елементів фразеологізму доводить, що той, хто говорить, не думає над окремими словами, і часто, сам того не підозрюючи, говорить нісенітницю чи такі речі, які б нізащо не сказав, коли б розумів, що це означає <... . При вивченні фразеології схильність до аналізу так само шкідлива, як при вивченні окремих слів: занадто глибоке лінгвістичне знання заважає проникненню в дух мови» [1, с. 101]. У цьому чи аналогічних випадках художню рівновагу між одиницями оригіналу і перекладу забезпечує не так глибокий аналітичний підхід і лінгвістична компетентність, як тонке мовне чуття, інтуїтивне передбачення й розвинений естетичний смак.

Випробуванням на перекладацьку майстерність стали й назви Стефаникових новел. Тут лаконізовано риси, властиві його художній манері загалом: глибина проникнення в психологію героїв, правдивість і відвертість у зображенні реалій життя, особлива гармонія змістоформи, економія художніх засобів.

Назва новели «Такий панок» проста й лаконічна. Здавалося б, тут немає ані складного ідейно-художнього та світоглядного узагальнення (як, скажімо, у новелі «Вона - земля»), ні додаткової символічної згущеності (як у «Кленових листках» чи в «Камінному хресті»), проте розмаїтість перекладацьких версій свідчить, що саме в цій простоті і криється чи не найбільша складність. Ось приклади: «Такой господин», «Чудной барин», «Чудный панок», «Панок с причудами», «Чудак», «Cudaczny panek». До слова, упорядники польськомовного видання 
(I. Байковська, Р. Чеканська-Гейманова, К. Марська, А. Ротецька) повністю орієнтувалися на російський варіант, що вийшов роком перед тим, і помилки російських перекладачів автоматично перейшли в польські тексти, хоч переклади і здійснювалися з українськомовного, але адаптованого до літературної мови оригіналу.

Більшість перекладачів чомусь поспішили витлумачити вказівний займенник (нейтральний) «такий» за допомогою експресивних означень «чудной» чи «с причудами», тобто підсилили емотивні семи. Так, панок, головний герой новели, «не такий», як усі інші пани, але ж який «такий» цей панок насправді? Можна навести 3 десяток епітетів, але й вони навіть наполовину не заповнять асоціативно-контекстуальної лакуни начебто нейтрального займенника. В. Дуткевич ризикнув залишити займенник «такий», але відтворив «панок», як «господин», тому загалом переклад вийшов невдалим. «Барин», «сударь», «господин» - це словникові - і не більше - відповідники до українського «пан». Культурно-естетичне поле цих слів у двох мовах, на що справедливо вказують О. Кундзіч і В. Россельс, не тотожне. Не можемо вважати адекватним оригіналові й варіант 3 яскраво вираженою етнокультурною семою «Чудной барин» (М. Ляшко). Мимоволі назва «Чудной барин» наближається до аналогічної назви нарису Г. Успенського «Чудак-барин». В. Стефаник справді дуже любив Г. Успенського і вчився в цього російського письменника. Одначе подібність творів закінчується лише подібністю заголовків. Перед нами цілком різні тексти. Цього перекладачі також не врахували. Г. Шипов і М. Пархоменко залишили в перекладному тексті українське слово «панок». Вони мимоволі (чи необережно) наділили Стефаника тією долею етнографізму, який абсолютно чужий його образно-художній системі. «Панок», завдяки здрібніло-пестливій формі, мимоволі сприймається 3 певною долею іронії. Маніфестація оказійної семи тут явно недоречна. Адже в новелі немає навіть натяку на карикатурність постаті героя.

То як відтворити цю «просту складну» назву? Гадаємо, найближче до оригіналу підійшов В. Россельс («Чудак»). Цей перекладач використав прийом змістового розвитку, тобто замінив словниковий відповідник контекстуальним, що логічно пов'язаний 3 першим. В. Россельс пожертвував задля досягнення функціональної рівноваги низкою асоціативно-суб'єктивних нюансів назви першотвору (невимушеністю, дотепністю), проте не розірвав особливого зв'язку між нею (назвою) і новелою, не привніс зайвих і недоречних аналогій і зв'язків.

Діалектну назву новели «Шкільник» М. Ляшко, Г. Шипов, В. Россельс відтворили механічно - «Школьник», «Uсzеń» (К. Марська). (․ М. С. Стецик, 2015. 
У сучасній російській мові слово «школьник» має одне значення: учень початкової чи середньої школи й відповідає українському «школяр». «Шкільник» В. Стефаника - це сирота, який усі життєві премудрості осягає за правилом: «все мус зробити сам». Стефаниківська назва перегукується $з$ горьківською (маємо на увазі «Мої університети»). На цьому прикладі знову ж таки бачимо парадоксальний закон перекладу: що буквальніше відтворюється слово, то далі від оригіналу буде переклад. У російській мові є діалектне слово «школяр» із семантикою «ученик плохого поведения» [3, т. 4, с. 449; 2, т. IV, с. 638]. Гадаємо, як варіант до «Шкільника» воно набагато більше підходить і в плані експресивному, і в плані стилістичному. Як стверджує В. Рагойша, «одні і ті ж слова у споріднених мовах викликають у носіїв цих мов різну емоційну реакцію. I якщо залишити їх без зміни у перекладному тексті, вони значною мірою прирікають переклад на звичайний буквалізм, i - як наслідок цього - на непоетичність» [7, с. 76].

Навіть ці спорадичні дослідження різночасових російських та польських версій новел В. Стефаника дають змогу акцентувати на важливих аспектах перекладу зі споріднених мов. Незначні відмінності на лексичному й граматичному рівнях набували принципового, навіть вирішального значення при будь-якій спробі механічно перенести Стефаникові слова й словесні образи у площину російської чи польської мови. Адже в мистецтві слова все тримається на отих «ледь-ледь», на найтонших відтінках, «летючих» нюансах, які знаменують неповторне обличчя і твору й творця. Позірна легкість перекладу із споріднених мов конкретно при перекладі Стефаникового художнього слова позначилася на тому, що механічно змодельовані підрядники не покривали своєю словесною формою динамічних, рельєфних одиниць першотвору, вивірялися зазвичай на рівні лексико-семантичних варіантів, а не на дотику лінгвістики, поетики, етнології.

\section{Література}

1. Балли Ш. Французская стилистика / Ш. Балли ; [пер. К. А. Долинина]. - М. : Изд-во иностр. л-ры, 1961. - 394 с.

2. Даль В. Толковый словарь живого великорусского языка : Т. 1 - 4 / В. Даль. М. : Русский язык, $1978-1980$.

3. Этимологический словарь русского языка / [сост. М. Фасмер] ; под ред. и с предисл. Ларина Б. Н. ; пер. с нем. и доп. чл.-корр. АН СССР Трубачева О. Н. - М. : Прогресс, 1986.- T. I - IV.

4. Зорівчак Р. Реалія і переклад (на матеріалі англомовних перекладів української прози) / Р. Зорівчак. - Львів : Вид-во при Львів. ун-ті, 1989.- 215 с. 
5. Новикова М. Прекрасен наш союз. Литература - переводчик - жизнь : Лит.крит. очерки / М. Новикова. - К. : Рад. письменник, 1986. - 224 с.

6. Погребенник Ф. П. Василь Стефаник у слов'янських літературах / Ф. П. Погребенник. - К. : Наукова думка, 1976. - 295 с.

7. Рагойша В. П. Проблемы перевода с близкородственных языков / В. П. Рогойша. - М. : Изд-во Белорус. гос. ун-та, 1980. - 184 с.

8. Рильський М. Мистецтво перекладу : Статті, виступи, нотатки / М. Рильський [упоряд. і комент. Г. Колесника]. - К. : Рад. письменник, 1975. - 344 с.

9. Словник бойківських говірок / [укл. Онишкевич М. Й.] - К. : Наукова думка, 1984. - Ч. 1.

10. Стефаник В. С. Повне зібрання творів : у 3-х т. / В. Стефаник. - К. : Вид-во АН УРCP, 1949-1954. - Т. 1.

11. Стефаник В. Избранные произведения / В. Стефаник [пер. : Г. Шипов, А. Деев ; предисл. С. Крижановского]. - М. : Гослитиздат, 1950. - 224 с.

12. Стефаник В. Избранные произведения / В. Стефаник ; [пер. : Н. Ляшко, Г. Шипов, А. Деев ; предисл. С. Крижановского]. - К. : Гослитиздат УССР, 1951. - 208 с.

13. Стефаник В. Избранное / В. Стефаник [пер. Г. Шипова, Н. Ляшко, В. Дуткевича, А. Деева ; предисл. С. Крыжановского ; сост. и коммент. В. Лесина]. М. : Худ. л-ра, 1971. -223 с.

14. Стефаник В. Новеллы / В. Стефаник [изд. подгот. Вл. Россельс]. - М. : Наука, 1983.- 228c.

15. Федоров А. В. Основы общей теории перевода : Лингвист. пробл. / А. В. Федоров. - [4-е изд., доп. и перераб]. - М. : Высшая школа, 1983. - 304 с.

16. Stefanyk W. Klonowe liscie. Z ukrainskiego przelozyl Michal Moczulski / W. Stefanyk. - Lwów, Ksiegarnia Polska, 1904.-176 s.

Стаття надійшла до редакиії 28.07.2015 p. 